\title{
Planar cell polarity, cilia, and human disease
}

JB Wallingford

From First International Cilia in Development and Disease Scientific Conference (2012)

London, UK. 16-18 May 2012

The planar cell polarity (PCP) proteins govern diverse cellular behaviors, are essential for embryonic development, and are associated in a variety of human birth defects, including ciliopathies. While many PCP proteins have been extensively characterized, the "PCP effector" proteins, Inturned, Fuzzy and Fritz, remain largely unstudied. We have shown that each of these novel proteins is broadly essential for ciliogenesis in vertebrate animals. Here, we will discuss our efforts to combine bioinformatics, genomics, mouse genetics, and in vivo time-lapse imaging of intraflagellar transport to understand the mechanisms by which the PCP proteins govern cilia structure and function.

Published: 16 November 2012

doi:10.1186/2046-2530-1-S1-K2

Cite this article as: Wallingford: Planar cell polarity, cilia, and human disease. Cilia 2012 1(Suppl 1):K2.

Submit your next manuscript to BioMed Central and take full advantage of:

- Convenient online submission

- Thorough peer review

- No space constraints or color figure charges

- Immediate publication on acceptance

- Inclusion in PubMed, CAS, Scopus and Google Scholar

- Research which is freely available for redistribution

\section{Biomed Central}

